INTERNATIONAL JOURNAL OF MULTIDISCIPLINARY RESEARCH AND ANALYSis

ISSN(print): 2643-9840, ISSN(online): 2643-9875

Volume 04 Issue 12 December 2021

DOI: 10.47191/ijmra/v4-i12-25, Impact Factor: 6.072

Page No.- 1944-1951

\title{
Standing Against Workplace Discrimination (2); Using Management Accounting Information (Balanced Scorecards)
}

\section{Cengiz Yılmaz}

Department of Business, Afyon Kocatepe University Gazlıgöl Yolu, ANS Kampusü, 03200 Afyon, Turkey

ABSTRACT: Discrimination in the workplace has been all through history, and it exists today, and there will be in the future. Some people suggest that get used to it and benefit from it. But this study suggests honest and honorable have to stand against Discrimination in the name of humanity, the rule of law, religion, and better management. The study suggests that one of the best ways to stand against Discrimination is to provide and use correct, reliable, and concrete managerial accounting information.

Kaplan and Norton (1992) developed balanced scorecards for managerial purposes and performance measurement. Balanced scorecards used for strategy designing of companies. In this study, balanced scorecards are designed and set to explore and exhibit the inappropriateness and discrimination in the workplace. In the model, balanced scorecards include managerial information such as time, quality of product, difficulty, authority, salaries, bonuses, Etc., to assess the appropriateness of decisions or existence of discrimination. These measurements are vital for providing concrete evidence for managerial or jurisdictional cases. Standing against discrimination in the workplace first requires power and determination. But secondly, it requires proof: documents. One of the most reliable documents is (management and cost) accounting information.

Discrimination during the promotion is characteristically an organized crime. Harmonious and compatible work of different individuals and organizations is essential for realizing crime. The realization of the law, the prosecution of an organized crime, and restoration of victims' rights require definitively provable, concrete documents and analysis. For this purpose, this study develops a managerial accounting information model that internal auditors and inspectors can efficiently use. It can also benefit decision-makers, business people, internal and external auditors, unions judges, and other governmental bodies to investigate or take decisions about workplace discrimination.

KEYWORDS: Discrimination at Workplace during Promotion Stage, Worthiness, Management accounting, Balanced Scorecards JEL Classification: H83; M12; M41; M42; M48; J71; M14; K31; I12; J16; J31; J53; Z13

\section{INTRODUCTION}

The business environment and the criteria affecting success have changed radically in today's globalized world. Today, competitive advantages such as access to raw materials, labor costs, and technological superiority, which used to be a competitive advantage, are not as significant as before. Because today, almost every business has easy access to raw materials wherever they are in the world. Similarly, companies can quickly access cheap labor (in China) or technical information (on the internet) and balance their competitive advantages. The main competitive advantage of today is the (executive or scientific) workforce. Yilmaz and Eleren (2012) found that the labor force in huge companies (employing qualified workers) is more competitive than the more minor employees (employing fewer quality workers). With a group of employees with high managerial and scientific skills, a business can maximize market share, employee satisfaction, and customer satisfaction. Therefore, it is strategically imperative to select and raise managers moderately and to uncover and correct discrimination in doing so. In their study, Kaplan and Norton (1996) developed the financial use of balancing scorecards. In this study, Kaplan and Norton's (1996) study was improved to expose discrimination during the promotion phase.

According to Pfeffer (1994), implementing more effective human resources management systems consistently contributes to competition. Nonetheless, according to Tapinos et al. (2011), there was no significant difference between businesses that implemented balancing scorecards and businesses that did not. Yilmaz and Demirhan (2016) found that human capital indicators contribute to both economic growth and labor productivity in their work for Balkan countries. 
Balancing scorecards developed as a management system to create and produce priority numerical data for management. Today, they are used to plan and realize strategic objectives and achieve strategic goals. From a strategic perspective, balanced scorecards guide decision-makers by measuring financial results and considering the results measured from other operational activities. Balance scorecards significantly contribute to senior management and sub-managers based on setting and measuring targets.

Kaplan and Norton (1992) examined balancing scorecards based on four perspectives. These are the Finance-based, customer, learning and development, and internal business activities. Agrawal (2008) developed the basic skill balanced scorecard model (based on basic data: Competency-Based Balanced Scorecard Model) based on human resources variables. According to Wisniewski and Dickson (2001), performance control with balanced scorecards is essential for accountability and transparency in the public sector. Ittner, Larcker, and Meyer (2003) examined how different performance criteria were weighted in financial services and used on balance scorecards. According to Lueg and Vu (2015), critical success factors (including support from senior management, speed of performance, cost-benefit analysis) are essential elements of balancing scorecards and strategic success. $\mathrm{Yu}$ et al. (2009) suggested that electronic balance scorecards can improve measuring academic staff performance and improve overall excellence.

Kaplan and Norton (1992) primarily focused on criteria that affected performance but then on criteria such as growth and learning. Beyond financial performance, Lipe and Salterio (2000) examined the impact of balanced scorecards on general and specific judicial (and management) decisions. Similarly, Ittner, Larcker and Meyer et al. (2003) focused on the weight of performance criteria. Dilla and Steinbart (2005) studied comparative consequences of non-comparable and general balance scorecard criteria. Over the years, the use of balancing scorecards has progressed from measuring and valuation to developing strategies. Within this framework, Kaplan and Norton (2000) studied the "strategy map" followed by Ittner, Lambert and Larcker (2003) on the "value drivers map".

In other words, balancing scorecards has become a strategy and decision-making instrument from being a measuring instrument. Campbell et al. (2008) studied and tested balancing scorecards and strategies developed on their basis, including multiple performance criteria. In all of these studies, balancing scorecards has been an essential instrument in defining, performing, and measuring strategies.

Bazerman et al. (2002) suggest that accountants do poor assessments during auditing; they assess organizations according to their prejudices when the targeted goals do not match the expectations. Bloomfield and Luft (2006) also indicated similar prejudices in management and cost accountants. Hunton and Mcewen (1997) argued that management accountants' preconceptions about performance and balance scorecards were reflected in the (biased) estimates of financial analysts along with motivational motives. Hales (2007) examined how the preferences directed (on the balance scorecards), and information transactions (artificial intelligence) affected investor estimates.

\section{CREATING SCORECARDS}

Balance scorecards show the results (scores) used to measure the extent to which managers achieve the enterprise's strategic objectives at the specified measurement time. Here, the word balance is used to indicate that linguistic criteria and numerical criteria (on the basis of measurement logic) should be balanced. There should be a balance between verbal criteria such as learning and numerical criteria. The only measurement of numerical data does not show actual performance or strategic success. Traditionally, financial success is considered a basic criterion for business and strategic success. Retrospective use of balancing scorecards and their indicators is called lag indicator: their output has been the result of past activities. For example, the result of the newly established production system or marketing strategy to the profit is a historical indicator. However, it is also sunk costs, considered old indicators, and usage for the future will not be appropriate. Besides, it can be said that lead indicators are more effective in developing an accurate and fair strategy for the future. It can be questioned, "Why are there only four performance criteria in balanced scorecards". These four criteria can be valuable and important, but why haven't health criteria or environmental criteria been included in them? These criteria are guiding, indicator criteria, a framework study. This framework is an (indicative) study that guides those who design strategies. Decision-makers can increase and decrease these four criteria according to their needs. The main thing here is the main objectives of the related company or the owner. According to these objectives, criteria should be set and designed. Managers/owners have to develop and apply the criteria in a balanced manner according to the needs of their businesses. For example, in an organization whose main purpose is to help the poor people, success measure: profit maximization cannot be a first-degree performance measure? In this case, management, by using his initiative, can subtract "financial performance" criteria and can replace it with the "number of poor people being helped" as the primary key performance measure in the strategic model he creates. Similarly, the human health or safety criterion can be the primary criterion in an industry where a dangerous job is done. 


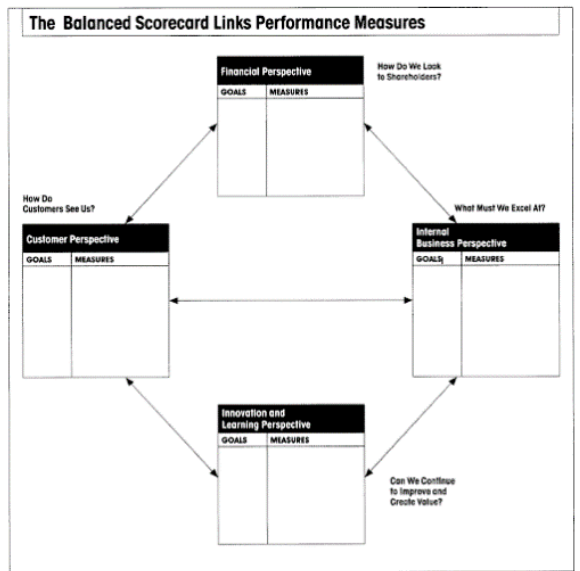

Fig. 1. The Balanced Score Card Model Developed by Dr. Robert Kaplan and Dr. David Norton in 1992. Source: Kaplan and Norton (1992)

\subsection{Financial Perspective}

The main financial goal of many businesses is to maximize profit. On this basis, the appropriate criteria are minimizing cost, maximizing revenue, and increasing the positive difference between revenue and costs (profit).

\subsection{Customers Perspective}

Most businesses can use the level of customer satisfaction as a criterion. This is a linguistic criterion. Measuring linguistic goals are complicated in terms of numbers. But they can be and should be converted into numbers to use for numeric analyses. While analyzing companies, there is a need for balanced, integrated information for both financial numerical data and linguistic values.

\subsection{Internal Business Perspective}

Measuring the level of activities carried out within the enterprise according to the pre-determined targets. One of the most apparent perspectives is undoubtedly costs. Whether or not the charges are maintained within the framework of the specified targets can be measured. However, verbal criteria are difficult to measure in numerical terms, such as product quality and taste. The peculiarity of balanced scorecards is that criteria can also include targets, business goals, and strategies.

\subsection{Innovation and Learning Perspective}

Employee learning skills can contribute to the enterprise much more than expected. Because learning skills can multiply the capabilities of employees and organizations from existing levels. Learning abilities: basic skills of the employee, training levels, compliance with the business culture, technological skills, and experience all contribute to the organization. Strategically It is essential to determine, measure, and analyze the learning and improving capabilities. Other strategies can be designed and implemented in the organization's innovation and learning capacities exist, or otherwise, it cannot be.

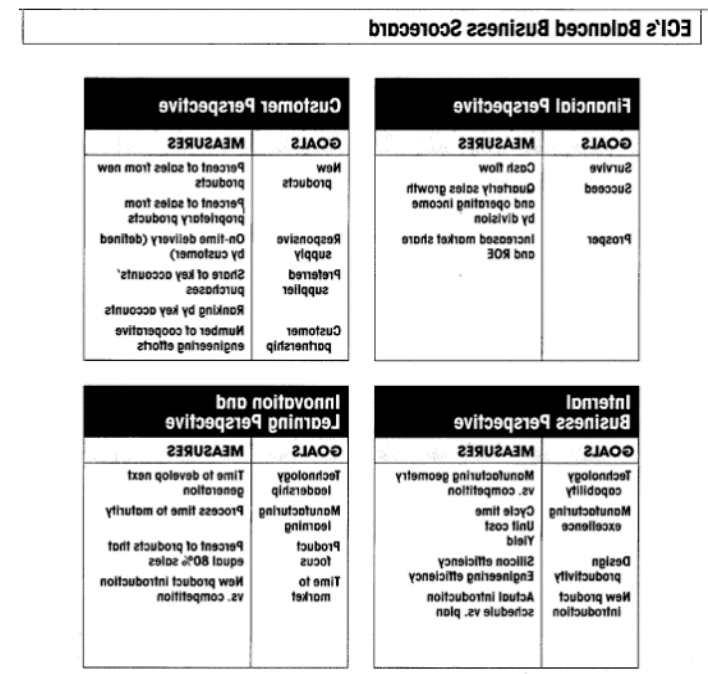

Fig. 2. ECl's Balanced Business Scorecard Source: Kaplan and Norton (1992)

3. SAMPLE MODEL FOR THE USE OF BALANCESKOR CARDS IN MANAGEMENT ACCOUNTING, DETERMINATION OF DISCRIMINATION DURING THE PROMOTION 
Management accounting reports correct, reliable, and appropriate information for decision making by representing different options, based on accountability and transparency, where other measurement units are used and analyzed.

Cost and management accounting information are prepared for the decision-makers and internal auditors. To make administrative decisions, decision-makers use local currency as in financial accounting and international currencies, kilogram, ton, meter, liter, kilo, and calorie in cost accounting. All these measurements and journal entries are the transactions' proof and reasonings based on openness and accountability. Balanced scorecards in management accounting contribute to feasibility studies related to future investments and operations. The answers to feasibility questions (when, where, how much raw material and how much labor can be spent by who) are measured and determined by balancing scorecards. Besides, labor costs also can be estimated and analyzed with balanced scorecards. Labor costs, production, and related managerial information are vital information used for promotion decisions. Rational decision-making provides correct and appropriate management-related ratios and numbers for good and better governance. Rational decision making also essential for fairness, as well.

The alarm function of management accounting is a neglected, unseen feature. Balancing scorecards provide information, ratios; predicting and alerting the potential problems before administrative problems occur. It warns managers, internal auditors, external auditors, and inspectors about possible executive risks. Warnings may provide specific information such as time and place. In the same way, it can operate the alarm function against the risks of discrimination during the promotion phase in the workplace. Let's look at this as an example.

In our example, two employees are working in a company. Their names are David CRAFTY and James NAIVE. Balancing scorecard models for their work at work have been designed. Core competencies are the essential skills that give an advantage in competition in a workplace. The number of products produced, quality of products, costs of products, accuracy, and compliance of the managerial decisions made are all core competencies of employees in the workplace. The table below represents a balanced scorecard for an organization; linguistic variables converted into numeric values such as the difficulty of work and product quantity.

Table 1. Employee David CRAFTY's Scorecard

\begin{tabular}{|c|c|c|c|c|c|c|c|c|c|c|c|c|c|}
\hline \multicolumn{4}{|c|}{ Last Name: David CRAFTY } & \multicolumn{10}{|c|}{ Department: Engine Repairing } \\
\hline $\begin{array}{l}\text { Process } \\
\text { No.: }\end{array}$ & Date & $\begin{array}{l}\text { Customer } \\
\text { Name }\end{array}$ & $\begin{array}{l}\text { Name } \\
\text { /Attribute of } \\
\text { the Job }\end{array}$ & $\begin{array}{l}\text { Start } \\
\text { Time }\end{array}$ & $\begin{array}{l}\text { End } \\
\text { Time }\end{array}$ & Time & $\begin{array}{l}\text { Overtime } \\
\text { Multiplier* }\end{array}$ & $\begin{array}{l}\text { Hourly } \\
\text { Rate }\end{array}$ & $\begin{array}{l}\text { Difficulty } \\
\text { Of Work }\end{array}$ & $\begin{array}{l}\text { Product } \\
\text { Quantity }\end{array}$ & $\begin{array}{l}\text { Product } \\
\text { Quality }\end{array}$ & Authority & $\begin{array}{l}\text { Labor } \\
\text { Cost }\end{array}$ \\
\hline DA1 & 01012016 & Ayse $\mathrm{Hm}$ & $\begin{array}{l}\text { Socket } \\
\text { replacement }\end{array}$ & 8 & 12 & 4 & 1 & 9 & 3 & 2 & 2 & Ş. Ö. & 36 \\
\hline DA2 & 01012016 & Mr. Zafer & $\begin{array}{l}\text { Engine oil } \\
\text { replacement }\end{array}$ & 13 & 18 & 5 & 1 & 6 & 4 & 1 & 1 & C.Y. & 30 \\
\hline DA3 & 01012016 & Ayse $\mathrm{Hm}$ & $\begin{array}{l}\text { Socket } \\
\text { replacement }\end{array}$ & 18 & 22 & 4 & 2 & 9 & 3 & 2 & 3 & Ş. Ö. & 72 \\
\hline DC4 & 02012016 & Mr. Deniz & engine test & 8 & 12 & 4 & 1 & 7 & 5 & 3 & 3 & C.Y. & 28 \\
\hline DA5 & 02012016 & Ayse $\mathrm{Hm}$ & $\begin{array}{l}\text { Socket } \\
\text { replacement }\end{array}$ & 13 & 18 & 5 & 1 & 9 & 3 & 2 & 2 & Ş. Ö. & 45 \\
\hline DA6 & 03012016 & Mr. Deniz & $\begin{array}{l}\text { Installing a } \\
\text { power line on } \\
\text { the wall }\end{array}$ & 13 & 18 & 5 & 1 & 7 & 6 & 5 & 2 & Ş. Ö. & 35 \\
\hline DA7 & 04012016 & Ayse $\mathrm{Hm}$ & $\begin{array}{l}\text { Socket } \\
\text { replacement }\end{array}$ & 8 & 12 & 4 & 1 & 9 & 3 & 2 & 2 & Ş. Ö. & 36 \\
\hline DA8 & 04012016 & Mr. Zafer & $\begin{array}{l}\text { Engine oil } \\
\text { replacement }\end{array}$ & 13 & 18 & 5 & 1 & 6 & 4 & 1 & 1 & C.Y. & 30 \\
\hline DA9 & 05012016 & Mr. Zafer & $\begin{array}{l}\text { Change of } \\
\text { spark plugs }\end{array}$ & 8 & 12 & 4 & 1 & 5 & 2 & 1 & 1 & Ş. Ö. & 20 \\
\hline DA10 & $\begin{array}{l}0601 \\
\text { Saturday } \\
2016 \\
\end{array}$ & Ayse $\mathrm{Hm}$ & $\begin{array}{l}\text { Installing a } \\
\text { power line on } \\
\text { the wall }\end{array}$ & 13 & 18 & 5 & 5 & 7 & 6 & 1 & 2 & ş. Ö. & 175 \\
\hline DA11 & $\begin{array}{l}0601 \\
\text { Saturday } \\
2016 \\
\end{array}$ & Mr. Deniz & $\begin{array}{l}\text { Socket } \\
\text { replacement }\end{array}$ & 13 & 17 & 4 & 5 & 9 & 3 & 1 & 4 & Ş. Ö. & 180 \\
\hline \multicolumn{6}{|l|}{ SUM } & 49 & 20 & 83 & 42 & 21 & 23 & & 687 \\
\hline
\end{tabular}

Data on basic skills provide much essential information based on Worthiness. Worthiness demonstrates the degree to which an employee is worthy of promotion. Some several criteria and measures can be used for Worthiness. For instance, the quantity of products produced; shows how many products the employee has produced during the accounting period and gives information about a candidate's production-related Worthiness. The employee who can make more in the specified time is more worthy of the relevant work. The amount of production can be a sign of Worthiness.

Similarly, attendance, networking hours, the difficulty of work, product quantity, product quality are all criteria representing the Worthiness of an employee. Besides, these criteria also illustrate the potential discrimination within the workplace. The balance scorecards used for companies' performance valuation in management accounting adapted to the worthiness criteria in the model. 
Standing Against Workplace Discrimination (2); Using Management Accounting Information (Balanced Scorecards)

Table 2: Employee James NAIVE's Scorecard

\begin{tabular}{|c|c|c|c|c|c|c|c|c|c|c|c|c|c|}
\hline Last Nam & : James NAIVE & Registry N & Departm & ent: Ele & city & & & & & & & & \\
\hline $\begin{array}{l}\text { Process } \\
\text { No.: }\end{array}$ & Date & $\begin{array}{l}\text { Customer } \\
\text { Name }\end{array}$ & $\begin{array}{l}\text { Name /Attribute of } \\
\text { the Job }\end{array}$ & $\begin{array}{l}\text { Start } \\
\text { Time }\end{array}$ & $\begin{array}{l}\text { End } \\
\text { Time }\end{array}$ & Time & $\begin{array}{l}\text { Overtime } \\
\text { Multiplier** }\end{array}$ & $\begin{array}{l}\text { Hourly } \\
\text { Rate }\end{array}$ & $\begin{array}{l}\text { Difficulty } \\
\text { Of Work }\end{array}$ & $\begin{array}{l}\text { Product } \\
\text { Quantity }\end{array}$ & $\begin{array}{l}\text { Product } \\
\text { Quality }\end{array}$ & Authority & $\begin{array}{l}\text { Labor } \\
\text { Cost }\end{array}$ \\
\hline VS1 & 01012016 & Ayse $\mathrm{Hm}$ & Engine rectification & 8 & 12 & 4 & 1 & 6 & 9 & 2 & 2 & ş. Ö. & 24 \\
\hline VS2 & 01012016 & Mr. Zafer & $\begin{array}{l}\text { Socket } \\
\text { replacement }\end{array}$ & 13 & 18 & 5 & 1 & 9 & 3 & 4 & 8 & C.Y. & 45 \\
\hline VS3 & 01012016 & Ayse $\mathrm{Hm}$ & Engine rectation & 18 & 22 & 4 & 1 & 6 & 9 & 2 & 3 & ş. Ö. & 24 \\
\hline VS4 & 02012016 & Mr. Deniz & $\begin{array}{l}\text { Installing a power } \\
\text { line on the wall }\end{array}$ & 8 & 12 & 4 & 1 & 7 & 6 & 6 & 8 & C.Y. & 28 \\
\hline VS5 & 02012016 & Ayse $\mathrm{Hm}$ & $\begin{array}{ll}\text { Engine } & \text { oil } \\
\text { replacement }\end{array}$ & 13 & 18 & 5 & 1 & 6 & 4 & 1 & 1 & ş. Ö. & 30 \\
\hline VS6 & 02012016 & Mr. Deniz & Engine rectation & 18 & 22 & 4 & 1 & 6 & 9 & 2 & 3 & Ş. Ö. & 24 \\
\hline VS7 & 03012016 & Ayse $\mathrm{Hm}$ & $\begin{array}{ll}\text { Engine } & \text { oil } \\
\text { replacement }\end{array}$ & 8 & 12 & 4 & 1 & 6 & 4 & 1 & 1 & Ş. Ö. & 24 \\
\hline VS8 & 03012016 & Mr. Deniz & $\begin{array}{l}\text { Socket } \\
\text { replacement }\end{array}$ & 13 & 18 & 5 & 1 & 9 & 3 & 4 & 9 & C.Y. & 45 \\
\hline VS9 & 03012016 & Ayse $\mathrm{Hm}$ & $\begin{array}{ll}\text { Engine } & \text { oil } \\
\text { replacement } & \end{array}$ & 18 & 22 & 4 & 1 & 6 & 4 & 1 & 1 & ş. Ö. & 24 \\
\hline VS10 & 04012016 & Ayse $\mathrm{Hm}$ & Engine rectation & 8 & 12 & 4 & 1 & 6 & 9 & 2 & 4 & ş. Ö. & 24 \\
\hline \multicolumn{6}{|l|}{ SUM } & 43 & & & 60 & 25 & 40 & & 292 \\
\hline
\end{tabular}

The information developed within the model framework and used to record, classify, analyze, evaluate, and make decisions about employees and their Worthiness is shown on the model balanced scorecards. Managerial accounting information gathered from balanced scorecards can be vital indicators for Discrimination in the workplace. Such indicators can give alerts; red flags to the management about consciously or unconsciously unseen critical problems. These existing problems or potential problems can be severe problems of the future.

These red flags should be explored, investigated, and solved by the lower-upper management, internal auditors. Existing and Potential problems should be solved and eliminated even before they occur. The study only involves identifying discriminatory administrative risks for employees at the promotion stage. This work should be developed with supportive studies (procurement, quality, price, employment, marketing) within different administrative issues.

\subsection{ANALYSIS OF BALANCE SCORECARDS: RED FLAGS}

3.1.1 Skeptical assignments (in non-specialist areas): Worthiness is the measurement of how an employee is worth to fit the profession in terms of knowledge, experience, and loyalty. Employees who have a high degree of Worthiness to fit their career in their specialties may produce better services and products. When employees are assigned to non-specialist areas, their productivity will naturally reduce. Employee David CRAFTY is an engine technician. But his eight assignments out of eleven (8/11= $72 \%)$ are related to his experience: electricity. On the other hand, James NAIVE's seven out of $10(7 / 10=70 \%)$ assignments relate to engine repairing even though he is an electrician. In exceptional cases, employees can work outside their specialty. But working out of specialized areas by $70 \%, 72 \%$, cannot be considered a common exception. It is an obvious sign of Discrimination that the related auditing bodies should investigate.

3.1.2 Working Time: The first employee worked 49 hours during the week, while the second employee worked 43 hours. Even though this can be a tolerable difference still, it should be examined whether this Discrimination is permanent or not.

3.1.3 Nightshift payments: Overtime and weekend payments are significant opportunities for the employees to generate additional incomes. That is why most white and blue-collar workers try to benefit from this opportunity. In this case, the first employee could benefit significantly from the night and weekend shifts; unfortunately, the second employee never got the chance to receive overtime pay.

3.1.4 A fair balance between the degree of work and the hourly rate: Deciding on hourly wage is a managerial decision. In the name of fairness, there should be a balance between the degree of difficulty and the salary. When the difficulty increases, wage also has to increase, or the other way around. The lack of a fair balance between them is a managerial problem and can lead to unfairness and Discrimination among employees during the remuneration and promotion phase. In our example, socket replacement's difficulty is only 3 degrees, which can be considered easy. But socket replacement's hourly payment is determined from the top 9 units. On the other hand, engine rectation, which is considered a difficult job and rated with 9 degrees of difficulty, 


\section{Standing Against Workplace Discrimination (2); Using Management Accounting Information (Balanced Scorecards)}

is waged with only six currency units. So, there is not a fair balance between the variables. This is a clear and concrete indicator of Discrimination. Although James NAIVE is an electrician, he can only get two electricity jobs (90 YTL), while Mr. David CRAFTY, who works as a motor technician, has been assigned to the job five times, one at the weekend, which is easy but with a very high return (369 YTL) job.

3.1.5 Product quantity/Production quantity per unit time: James NAIVE worked for a total of 10 hours to produce eight products (1.25 products/hour), while David CRAFTY, who worked as an engine master, was able to make nine products in 21 hours (1.33 products/hour).

Product quality: James NAIVE's Socket replacement job quality per unit is $(17 / 2=) 8.5$, whose primary expertise is electricity. On the other hand, engine expertise David CRAFTY, even though he is not an electrician, changed five sockets during the same accounting period, and his average product quality is $(13 / 5=) 2.6$ way below the first employee's average. But persistently advantageous easy and high-income job assignments are given to the specific employee. This can be a concrete proof or indication of Discrimination in the workplace.

3.1.6 Authority: Two essential management and management accounting principles are openness and Accountability. The authority should clearly and stand by their decision declare it with his signature. Moreover, in the official documents, the decision should be explained because of Accountability to audit the compliance of decisions with the law and fairness (administrative auditing). Balanced scorecards can reveal which manager made the decision. In our example, S.Ö., one of the decision-making authorities, made its decisions against James NAIVE, who worked in favor of Mr. David CRAFTY, the master of the motor. So balanced scorecard can prove the necessary amount of concrete and correct information about workplace discrimination.

3.1.7 Cost: is one of the most critical factors that affect the competitiveness of an organization together with product quality. Production with lower cost is one of the essential objects of a company. In the sample, Mr. David CRAFTY socket replacement business costs 41YTL per unit, while the cost of replacing an outlet by Mr. James NAIVE is 11.25 YTL. Balanced scorecards and analysis clearly show that there is a vital cost and quality problem in the workplace, which can critically harm the company's competitiveness and harm the reputation of the company in front of jurisdiction and public conscience.

Balancing scorecards are used to produce rational information on critical points that need to be audited and examined from a managerial point of view, depending on the model created. In this example, numerical examples were created for producing, recording, and analyzing the information used in employees' wages and promotion phases with balanced scorecards. According to this example, Mr. David CRAFTY was promoted as a foreman, while James NAIVE has to stay as a worker. Controversially, the balanced scorecard data clearly shows that employees are assigned outside their areas of expertise. There is Discrimination, including decisions related to working time. There are discriminatory decisions related to overtime payments (night weekend swifts). There is no fair balance between the degree of difficulty of the work and the hourly wage. There are no fair wages and promotions regarding product quantity and product quality. The authorities that make decisions contrary to merit are revealed in openness and Accountability. The relationship between cost and benefit has been ignored. All this evidence is or can indicate severe negligence or misconduct of duty in the workplace.

\section{DISCRIMINATION IN THE WORKPLACE AS AN ORGANIZED CRIME: HEAVY NEGLIGENCE OR MISCONDUCT OF DUTY}

Transfer of management is a power of attorney decision. Business owners transfer their management rights to professional managers. This agreement is a legal transaction between at least two parties. In the private sector, the company owners transfer the management right to the professionals. Similarly, responsible governmental bodies transfer their administrative rights to professionals in public enterprises. Managers who receive the right to be a manager with the power of attorney agreement made have to protect the rights and interests of the business owners and the public following the administration of attorney agreement. This Power of Attorney agreement also requires compliance with all kinds of legal rules: including non-discrimination in local and international laws and regulations.

The benefit of the state and business owners requires working more efficiently and not discriminating workers in the workplace. Operational efficiency in cost and quality can be increased by being fair among the employees. Acting against local and international rules and regulations will be punished, and the organization will be damaged. So, a professional manager has to make his decisions professionally. A person can be appointed to management because he is a professional and knows the rules of law and governance. Rookies are not and should not be appointed as professionals. Appointment of rookies who do not know the law and administrative rules is a crime against the attorney contract.

Any decision at the promotion stage is an organized decision between several parties such as engineers, lower, middle and upper management; they make the decision together in an organized way. They have or should have their signatures on the decision. If there is a decision that includes Discrimination, it also has to be an organized decision. A bureaucratic formation takes 


\section{Standing Against Workplace Discrimination (2); Using Management Accounting Information (Balanced Scorecards)}

decisions: first-level authorities, middle management, and the upper ones. So, the nature of the promotion decision is an organized decision.

A group of professionals' faults in promotion decisions can only be severe negligence or misconduct of duty during the promotion. Because of its nature, any favoritism decision or Discrimination during the promotion should include negligence or misconduct that horribly affects the lives of innocent employees and their families. This crime can not be committed alone. It can only be realized with synchronization in an organized way. In practice, it is almost impossible or complicated to commit this crime on her own individually. So, during the promotion phase, Discrimination is naturally an organized crime, and it should be punished accordingly.

\section{DISCUSSION, CONCLUSIONS, AND RECOMMENDATIONS}

Discrimination is the act of discriminating the people according to their colors, beliefs, religions, races, classes, richness, and poor nesses and transferring their rights and earning unfairly to the undeserved ones. Discrimination is a constitutional crime, a religious sin, a crime against humanity. Discrimination is usually done once or twice, and it finishes. But Discrimination during the promotion phase in the workplace does not end so soon. The effect of Discrimination takes days, weeks, months, and years. Workplace discrimination affects the lives of workers, partners, and children harshly. So, the injustice committed during the promotional phase is much more crime, more sin, and more crime against humanity than any ordinary discrimination. Much more criminals, and sinners may suggest that there was Discrimination in the past, there is at the moment and there will be in the future. They suggest victims have to be used to the Discrimination and bother the perpetrators.

But, human dignity, the rule of law, and beliefs (religion) say/orders that instead of getting used to Discrimination, oppose Discrimination.

There are several discrimination studies carried out in the past, and several studies have been carried out now; most probably, there will be several studies carried out in the future. It is and will be a popular subject because there is an enormous amount of people (partners, children, relatives, et.) affected by it.

Various variables and decision-making mechanisms can be used during the promotion phase. One criterion can be worthiness (in terms of knowledge, experience, and loyalty to the leading organization). In the developed model, various criteria were used to measure the specified criteria. These criteria give clear indication/proofs to the related parties based on fairness. The model created can be used as a future-oriented model that can be used during the preference phase. It can also be used to measure how decisions are discriminatory or not. This model can be used by decision-makers and auditors (internal auditors and external auditors). Legal decision-makers can also use it in countries where Discrimination is a constitutional crime.

Balancing score and their use in multiple decision-making mechanisms will also guide future research. Perhaps better, more effective methods will be developed and designed. It is clear that as long as there is Discrimination, such studies/practices will be needed in the future too. Because the crime of Discrimination has existed throughout history, it exists in almost all geographies, and it will probably happen in the future. In this respect, honest people, people who believe in the law, trust in divine justice, and believe in humanity, have to use these methods to fight Discrimination and stop injustices.

Discrimination during the promotion is characteristically an organized crime. Harmonious and organized work of different individuals and organizations is essential for realizing crime. The realization of the law, the prosecution of an organized crime, and restoration of victims' rights require definitively provable, concrete documents and analysis. For this purpose, this study develops a managerial accounting information model that internal auditors and inspectors can efficiently use. It can also benefit decisionmakers, business people, internal and external auditors, unions judges, and other governmental bodies to investigate or take decisions about workplace discrimination.

\section{REFERENCES}

1) Agrawal, S. (2008). Competency Based Balanced Scorecard Model: An Integrative Perspective, Indian Journal of Industrial Relations, Vol. 44, No. 1, Ss. 24-34

2) Bazerman M. H., Loewenstein, G. \& Moore D. A., (2002) Why Good Accountants do Bad Audits. Harvard Business Review, 80 (11): 96-102.

3) Bloomfield, R. J., \& Luft, J. L. (2006). Responsibility for Cost Management Hinders Learning to Avoid the Winner's Curse. The Accounting Review 81 (1): 29-47.

4) Brouwers, EPM, Mathijssen J,Van Bortel T, Knifton L. (2015) Discrimination in the Workplace, Reported by People With Major Depressive Disorder: A Cross-Sectional Study in 35 Countries. BMJ Open 2016;6:E009961. Doi:10.1136/Bmjopen2015-009961 (Accessed 01-06-2021). 
5) Campbell, D., S.M. Datar, S. L. Kulp, \& Narayanan, V. G.. (2008) Testing Strategy with Multiple Perfor Mance Measures: Evidence From a Balanced Scorecard a Store24. Working Paper, Harvard Business School.

6) Dilla, W. N., \& Steinbart, P. J.. (2005). Relative Weighting of Common and Unique Balanced Scorecard Measures by Knowledgeable Decision Makers. Behavioral Research in Accounting 17: 43-53.

7) Dressler, W. W. (1990) Lifestyle, Stress, and Blood Pressure in a Southern Black Community. Psychosom. Med. 52: 182198,

8) Friedman, M (1970). "The Social Responsibility of Business is to Increase Its Profits," New York Times Magazine.

9) Ghumman, S., Ryan, A.M., Barclay, L. A., \& Markel, K. S. (2013). Religious discrimination in the workplace: A review and examination of current and future trends. Journal of Business and Psychology,28, 439-454.

10) Hales, J. (2007). Directional Preferences, Information Processing, and Investors' Forecasts of Earnings. Journal of Accounting Research, 45 (3): 607-628.

11) Hunton, J. E., \& Mcewen R. A. (1997). An Assessment of the Relation Between Analysts' Earnings Forecast Accuracy, Motivational Incentives and Cognitive Information Search Strategy. The Accounting Review, 72 (4): $497-515$.

12) Ittner, C. D., Lambert, R. A. \& Larcker, D. F. (2003). The Structure and Performance Consequences of Equity Grants to Employees of New Economy Firms. Journal of Accounting and Economics,s 34 (1-3): 89-127.

13) Ittner, C. D., Larcker, D. F. \& Meyer, M. W. (2003), Subjectivity and The Weighting of Performance Measures: Evidence From a Balancedscorecard. The Accounting Review, Vol. 78, No. 3 Ss. 725-758

14) Kaplan, R. S., \& Norton, D. P. (1996) The Balance Scorecard, Boston, Harvard Business Press, 82.

15) Kaplan, R. S., Norton, D. P., \& David P.. (2000). Having Trouble with Your Strategy? Then Map it. Harvard Business Review, C: LXXVIII, No: 5, S.167- 176.

16) Kaplan, R. S., and Norton, D. P. (1992). The Balanced Scorecard? Measures That Drive Performance. Harvard Business Review 70 (1): 71-79.

17) Kaplan, R. S., and Norton, D. P. (1996) The Balance Scorecard, Boston, Harvard Business Press, 82.

18) Lipe, M. G., \& Salterio, S. E. (2000). The Balanced Scorecard: Judgmental Effects of Common and Unique Performance Measures. The Accounting Review 75 (3): 283-298

19) Lueg, R. \& Vu, L. (2015) Success Factors in Balanced Scorecard Impedances - A Literature Review, Management Revue, Vol. 26, No. 4, Ss. 306-327.

20) Tapinos, E., DysonR. G. \& Meadows M. (2011) The Journal Of The Operational Research Society, Vol. 62, No. 5, Special Issue: OR'sContribution To Supporting Strategy, Pp. 888-899

21) Wisniewski M. \& Dickson, A. (2001). Measuring Performance in Dumfries and Galloway Constabulary With The Balanced scorecard. The Journal of The Operational Research Society, Vol. 52, No. 10, Pp.1057-1066

22) Yilmaz, C. \& Demirhan, B. (2016) Long-Term Impact of Human Capital on Economic Growth: A Panel Data Analysis on the Balkan Countries, British Journal Of Economics, Management \&Trade, 13(1): 1-12.

23) Yilmaz C., and Eleren., A. (2012) Assessment of Turkish Ceramic Manufacturing Companies' Competitiveness and Compatibilities to EU in Consideration of Porter's Five Forces Model, China-USA Business Review, ISSN 1537-1514, Vol. 11, No. 11, 1502-1514.

24) Yu, M. L., Hamid, S., Ijab, M. T. \& So, H. P. (2009), The E-Balanced Scorecard (E-BSC) For Measuring Academic Staff Performance, Excellence Higher Education, Vol. 57, No. 6 Ss. 813-828 